\title{
ARHGAP5 Gene
}

National Cancer Institute

\section{Source}

National Cancer Institute. ARHGAP5 Gene. NCI Thesaurus. Code C97279.

This gene is involved in the regulation of GTPase activity. 